JAMP: Jurnal Adminitrasi dan Manajemen Pendidikan

Volume 1 Nomor 2 Juni 2018, Hal :171-178

Tersedia Online di http://journal2.um.ac.id/index.php/jamp/

ISSN 2615-8574 (online)

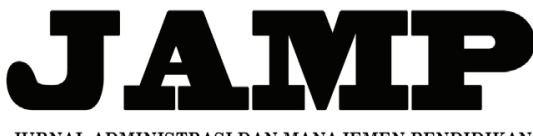

JURNAL ADMINISTRASI DAN MANAJEMEN PENDIDIKAN

\title{
PENGELOLAAN PERSIAPAN AKREDITASI SEKOLAH
}

\author{
Emilia Nur Chasanah Sholihin \\ Ibrahim Bafadal \\ Asep Sunandar \\ emilia.solihin@gmail.com \\ Universitas Negeri Malang, Jl. Semarang No. 5 Malang 65145
}

\begin{abstract}
The purposes of this research to describe: (1) the process of establishing school accreditation teams, (2) completing accreditation instruments and physical evidence, (3) inhibiting and supporting factors in preparation of school accreditation, (4) quality control of process completing accreditation instrument and physical evidence, (5) follow-up preparation of school accreditation, and (6) successful strategies in school accreditation. This research uses a qualitative approach, with a case study research design. Research location at SDN Ketawanggede Malang. Data collection techniques with interviews, observation, and documentation. The results of this research (1) the process of establishing the team through the appointment of the team leader by the principal, drafting SK, meeting and making SK team, (2) completing the accreditation instrument and physical evidence through attending socialization, checklist of accreditation instruments, preparation of accreditation data and fulfillment of physical evidence, (3) inhibiting factors such as time constraints, the existence of teacher mutation, pension and death, the document is irregular and printer is inadequate while the supporting factors are principal assistance and motivation, inter-team collaboration, and assistance of school stakeholders (4) control through checks and evaluation meetings, (5) follow-up preparations by familiarizing the completeness of school equipment, establishing school programs, and undertaking quality assurance through the SPMI team, and (6) success strategies in school accreditation there are strategies to get score A values and strategies for rapid done.
\end{abstract}

Keywords: management, preparation, school accreditation

\begin{abstract}
Abstrak : Penelitian ini bertujuan untuk mendeskripsikan: (1) proses pembentukan tim akreditasi sekolah, (2) pelaksanaan pengisian instrumen akreditasi dan bukti fisik, (3) faktor penghambat dan pendukung dalam persiapan akreditasi sekolah, (4) quality control dari proses pengisian instrumen akreditasi dan bukti fisik, (5) tindak lanjut persiapan akreditasi sekolah, dan (6) strategi keberhasilan dalam akreditasi sekolah. Penelitian ini menggunakan pendekatan kualitatif, dengan rancangan penelitian studi kasus. Lokasi penelitian di SDN Ketawanggede Malang. Teknik pengumpulan data dengan wawancara, observasi, dan dokumentasi. Hasil penelitian ini (1) proses pembentukan tim melalui penunjukan ketua tim oleh kepala sekolah, membuat draft SK, rapat dan membuat SK tim, (2) pelaksanaan pengisian instrumen akreditasi dan bukti fisik melalui menghadiri sosialisasi, melakukan checklist instrumen akreditasi, persiapan data akreditasi dan pemenuhan bukti fisik, (3) faktor penghambat yaitu keterbatasan waktu, adanya guru mutasi, pensiun dan meninggal dunia, dokumen letaknya tidak beraturan dan printer kurang memadai sedangkan faktor pendukung yaitu bantuan dan motivasi kepala sekolah, kerja sama antar tim, dan bantuan stakeholders sekolah (4) quality control melalui pengecekan dan rapat evaluasi, (5) tindak lanjut persiapan dengan membiasakan kelengkapan perangkat sekolah, membuat program sekolah, dan melakukan penjaminan mutu melalui tim SPMI, dan (6) strategi keberhasilan dalam akreditasi sekolah terdapat strategi untuk mendapatkan nilai A dan strategi supaya cepat selesai.
\end{abstract}

Kata Kunci : pengelolaan, persiapan, akreditasi sekolah 
Tuntutan masyarakat terhadap sekolah untuk terus meningkatkan mutu pendidikan harus mendapatkan respon yang bijaksana dan cepat. Hal ini tentunya menuntut sekolah untuk terus mengembangkan serta meningkatkan kualitas dalam segala aspek pengelolaan pendidikan, yaitu pengelolaan peserta didik, tenaga pendidik dan kependidikan, kurikulum dan pembelajaran, sarana dan prasarana, keuangan, serta hubungan sekolah dan masyarakat. Menyadari pentingnya proses peningkatan kualitas pendidikan, maka pemerintah terus berupaya mewujudkan hal tersebut. Salah satu cara yang dilakukan yaitu melalui akreditasi sekolah.

Berdasarkan Undang-Undang Sistem Pendidikan Nasional Nomor 20 Tahun 2003 Bagian Penjelasan dinyatakan bahwa "salah satu strategi pembangunan nasional melalui evaluasi, akreditasi, dan sertifikasi pendidikan yang memberdayakan". Adanya akreditasi sekolah dapat memetakan mutu pendidikan berdasarkan Standar Nasional Pendidikan serta menjadi acuan dalam upaya peningkatan mutu dan rencana pengembangan sekolah/madrasah (Pedoman Akreditasi BAN-SM, 2014: 8). Standar Nasional Pendidikan merupakan kriteria minimal sistem pendidikan yang mana ruang lingkup atau komponenkomponennya harus dipenuhi oleh sekolah sebagai penjamin mutu pendidikan. Ruang lingkup Standar Nasional Pendidikan berdasarkan Peraturan Pemerintah No 32 Tahun 2013 tentang Standar Nasional Pendidikan pasal 2 ayat 1 meliputi: "(1) standar isi; (2) standar proses; (3) standar kompetensi lulusan; (4) standar pendidik dan tenaga kependidikan; (5) standar sarana dan prasarana; (6) standar pengelolaan; (7) standar pembiayaan; dan (8) standar penilaian pendidikan".

Kenyataannya dalam melakukan akreditasi sekolah tidak berjalan dengan mudah karena banyak permasalahan yang terjadi. Permasalahan yang sering terjadi seperti persiapan yang dilakukan oleh sekolah terburu-buru, bukti fisik yang belum cukup, panduan akreditasi yang belum lengkap, sekolah tidak memiliki waktu untuk melakukan evaluasi diri serta kurangnya koordinasi dan komunikasi antar individu maupun tim. Menurut Hendarman (2014:80) permasalahan yang terjadi dalam melakukan akreditasi sekolah yaitu pada aspek konsep, instrumen, infrastruktur, administrasi, dan sumber daya manusia. Berdasarkan permasalahan-permasalahan tersebut, dapat diketahui bahwa munculnya permasalahan dikarenakan sekolah tidak melakukan persiapan dalam melakukan akreditasi dengan matang dan baik. Sekolah seharusnya melakukan persiapan dengan matang dan tidak menanggap remeh terhadap akreditasi sekolah, seperti di SDN Ketawanggede Malang.

Peneliti memilih SDN Ketawanggede Malang karena, adanya persiapan yang matang untuk menghadapi akreditasi sekolah melalui berbagai strategi yang diterapkan supaya berhasil dalam mencapai akreditasi yang tinggi. Meskipun seharusnya sudah akreditasi tahun 2017 diundur karena adanya pembatasan kuota dan baru mendapatkan kuota akreditasi pada tahun 2018. Hal tersebut tetap dimanfaatkan sekolah untuk melakukan persiapan akreditasi hingga akhirnya benar-benar mendapatkan panggilan untuk segera akreditasi. Selain itu, SDN Ketawanggede. merupakan sekolah re-grouping pada tahun 2013, sehingga akreditasi pada tahun 2018 merupakan pertama kali setelah adanya regrouping. Hal tersebut membuat personil sekolah melakukan persiapan yang matang, terlebih lagi dibawah kepemimpinan kepala sekolah yang juga baru. Sekolah tidak hanya melibatkan pihak internal sekolah tetapi juga pihak eksternal untuk terus bisa mendukung sekolah. Melalui pengalaman beberapa guru serta staf sekolah yang pernah mendapatkan hasil akreditasi A sebelum adanya re-grouping juga digunakan sebagai acuan dalam melaksanakan akreditasi yang sekarang. Ditambah lagi dengan berbagai prestasi yang sudah diraih sekolah seperti menjadi sekolah adiwiyata, pemenang ke-3 Malang Green School Festival, prestasi yang diraih oleh siswa baik prestasi akademik maupun non-akademik serta prestasi yang diraih oleh kepala sekolah yang menjadi juara 1 kinerja kepala sekolah se-kota Malang. Pencapaian yang telah diperoleh tersebut sangat mendukung dalam melakukan persiapan akreditasi untuk bisa mendapatkan hasil yang maksimal.

\section{METODE}

Penelitian ini menggunakan pendekatan kualitatif, dengan rancangan penelitian studi kasus. Teknik pengumpulan data diperoleh melalui wawancara mendalam, observasi berpartisipasi dan dokumentasi. Penelitian ini dimulai dengan mengumpulkan data di lapangan yang merupakan situs penelitian yaitu 
SDN Ketawanggede. Data penelitian yang telah diperoleh kemudian dilakukan analisis dengan cara mereduksi data sesuai dengan kode yang telah dibuat sebelumnya. Data tersebut kemudian disajikan dan ditarik menjadi sebuah kesimpulan. Key informan dalam penelitian ini adalah kepala sekolah, sedangkan data pendukung lainnya diperoleh melalui informan tambahan yaitu guru, Tenaga Administrasi Sekolah (TAS) dan penjaga sekolah. Pengecekan keabsahan data dilakukan peneliti bertujuan untuk mempertanggung jawabkan kebenaran data yang telah diperoleh. Keabsahan data dilakukan melalui teknik kredibilitas yaitu ketekukan dalam melakukan pengamatan, triangulasi, perpanjangan waktu pengamatan, kecukupan bahan referensi dan pengecekan anggota. Keabsahan data juga dilakukan dengan teknik ketergantungan dan kepastian.

\section{HASIL}

\section{Proses Pembentukan Tim Akreditasi Sekolah}

Proses pembentukan tim akreditasi di SDN Ketawanggede dilakukan melalui beberapa tahap yaitu, (1) kepala sekolah menunjuk guru untuk dijadikan sebagai ketua tim akreditasi sekolah. Penunjukan tersebut didasarkan pada kemampuan dan pengalaman, (2) kepala sekolah membuat draft SK yang berisi struktur tim akreditasi. Kepala sekolah membuat susunan nama sesuai struktur yang nantinya bertanggung jawab pada posisinya. Posisi yang harus ditempati yaitu wakil ketua, sekertaris, bendahara, koordinator dan anggota setiap 8 standar. Penempatan didasarkan sesuai dengan kemampuan yang dimiliki oleh masing-masing personil. (3) melakukan rapat menyampaikan struktur tim akreditasi untuk disepakati secara bersama dan (4) membuat SK tim berdasarkan hasil kesepakatan pada rapat.

\section{Pelaksanaan Pengisian Instrumen Akreditasi dan Bukti Fisik}

Pelaksanaan pengisian instrumen akreditasi dan bukti fisik di SDN Ketawanggede dilakukan melalui beberapa tahap yaitu, (1) mengikuti sosialisasi akreditasi sekolah yang diadakan oleh pengawas dari Dinas Pendidikan Kota Malang. Pada saat sosialisasi tersebut sekolah diberikan instrumen akreditasi serta diberikan penjelasan dari setiap poin yang ada di 8 standar, (2) melakukan checklist pada instrumen akreditasi yang diberikan oleh pengawas. Pengisian atau checklist instrumen dilakukan sesuai target tinggi yang dimiliki sekolah serta disesuaikan melalui data Evaluasi Diri Sekolah (EDS), (3) melakukan persiapan data yang dijadikan sebagai bukti fisik. Data atau dokumen yang digunakan untuk akreditasi ada yang disiapkan jauh-jauh hari sebelum akreditasi dan ada juga yang disiapkan menjelang akreditasi dan (4) melaksanakan pemenuhan bukti fisik sesuai poin yang ada di instrumen akreditasi. Bukti fisik yang digunakan untuk melengkapi setiap poin dalam instrumen bisa berupa dokumen serta berupa foto.

\section{Faktor Penghambat dan Pendukung dalam Persiapan Akreditasi Sekolah}

Faktor penghambat dalam persiapan akreditasi di SDN Ketawanggede beserta solusinya yaitu (1) keterbatasan waktu karena bersamaan dengan tugas dan kegiatan yang lain. Solusi yang dilakukan yaitu membuat jadwal atau mengatur waktu, membuat skala prioritas dan melakukan pembagian tugas, (2) adanya guru yang mutasi, penisun dan meninggal dunia. Solusi untuk guru yang sudah mutasi dan pensiun yaitu menghubungi guru yang mutasi untuk mengirimkan file tersebut dengan bantuan kepala sekolah yang menghubungi guru tersebut. Sedangkan jika ada guru yang meninggal solusinya bisa dengan mencari dokumen atau softfile. (3) bukti fisik berupa dokumen letaknya tidak beraturan dan bukti fisik berupa foto terkadang tidak ada kerena banyak kegiatan yang sudah dilakukan tetapi tidak didokumentasikan. Solusi yang dilakukan dengan mencari dokumen lama, bisa meminta bantuin ke anggota tim yang lain dan apabila ada dokumen yang tidak dapat ditemukan bisa share di grup whatsapp mungkin ada yang memiliki dokumen tersebut, dan (4) fasilitas yang kurang memadai yaitu berupa printer. Solusi untuk mengatasi hambatan tersebut yaitu menggunakan printer yang ada ruangan lain dan mencetak sendiri luar sekolah. Faktor pendukung dalam persiapan akreditasi di SDN Ketawanggede yaitu (1) adanya bantuan dan motivasi yang diberikan oleh kepala sekolah, (2) kerja sama yang baik antar seluruh tim akreditasi sekolah, (3) bantuan dari stakeholders sekolah meliputi pengawas sekolah, komite sekolah dan paguyuban sekolah atau orang tua siswa, dan (5) adanya dokumen yang dimiliki oleh sekolah meliputi data Evaluasi Diri Sekolah (EDS) dan dokumen yang digunakan saat lomba. 


\section{Quality Control dari Proses Pengisian Instrumen Akreditasi dan Bukti Fisik}

Quality control dari proses pengisian instrumen akreditasi dan bukti fisik di SDN Ketawanggede dilakukan melalui beberapa cara yaitu, (1) pengecekan bukti fisik yang dilakukan secara runtut mulai dari masing-masing koordinator standar, ketua tim, kepala sekolah dan pengawas. Pengecekan juga dilakukan dengan menggunakan lembar kontrol dengan tujuan untuk mempermudah melakukan pengecekan sehingga nantinya tidak ada poin standar yang terlewatkan, dan (2) melalui rapat evaluasi persiapan akreditasi sekolah setiap hari jumat. Rapat dilakukan untuk mengetahui sejauh mana perkembangan dari masing-masing standar. Selain itu bisa menyampaikan kendala apa saja yang dihadapai. Jadi, pada saat rapat itu bisa langsung dicarikan solusinya secara bersama-sama.

\section{Tindak Lanjut Persiapan Akreditasi Sekolah}

Tindak lanjut persiapan akreditasi di SDN Ketawanggede dilakukan melalui beberapa upaya yaitu, (1) membiasakan kelengkapan semua perangkat sekolah dengan berorientasi pada mutu. Hal tersebut dilakukan supaya lebih terbiasa dalam melakukan kegiatan apapun arahnya ke mutu yang nantinya menjadi budaya tersendiri di sekolah. Selain itu juga bisa mempermudah pada saat akan ada akreditasi lagi, (2) membuat rancangan program sekolah yang baru. Hasil yang diperoleh nantinya bisa menunjukkan letak kekurangan dari masing-masing standar. Berdasarkan kekurangan tersebut bisa digunakan sebagai pertimbangan untuk membuat program sekolah yang baru, dan (3) melakukan penjaminan mutu melalui tim SPMI (Sistem Penjaminan Mutu Internal). Tim SPMI melakukan berbagai evaluasi sehingga penilaiannya sesuai dengan kenyataan dan tidak dimanipulasi. Selain itu juga melakukan pengembangan sekolah sebagai bentuk persiapan akreditasi yang akan datang. Sehingga prosesnya tidak berhenti setelah akreditasi, melainkan selalu berkesinambungan.

\section{Strategi Keberhasilan dalam Akreditasi Sekolah}

Strategi keberhasilan dalam akreditasi di SDN Ketawanggede ada dua. Strategi pertama dilakukan untuk memperoleh nilai A meliputi memiliki target tinggi dan adanya pembagian kelompok dalam SK tim. Kedua, strategi supaya cepat selesai melakukan pengisian instrumen akreditasi meliputi melakukan kerja sama, koordinasi, komunikasi, saling membantu dan melakukan pembagian tugas.

\section{PEMBAHASAN}

Proses pembentukan tim di SDN Ketawanggede menunjukkan adanya penerapan fungsi manajamen yaitu organizing atau pengorganisasian. Hal tersebut seperti pendapat dari Kurniadin dan Machali (2012: 240) pengorganisasian (organizing) merupakan proses pembentukan sistem dan penyusunan anggota dalam bentuk struktur organisasi untuk mencapai tujuan organisasi. Proses pembentukan tim akreditasi diawali dengan penunjukan ketua tim yang dilakukan secara langsung oleh kepala sekolah sebagai seorang pimpinan kemudian membuat susunan nama sesuai struktur yang nantinya bertanggungjawab pada posisinya. Penunjukan dan penempatan tersebut didasarkan pada kemampuan dan pengalaman. Sesuai dengan pendapat dari Sagala (2013: 94) "dalam mengorganisasikan seorang manajer jelas memerlukan kemampuan memahami sifat pekerjaan (job specification) dan kualifikasi orang yang harus mengisi jabatan". Pelaksanaan rapat menjadi tahapan selanjutnya setelah kepala sekolah membuat susunan nama sesuai dengan posisi pada struktur tim. Pada rapat tersebut bertujuan untuk mencapai kesepakatan bersama dari masing-masing anggota tim, sehingga keputusan tersebut bukan dari keputusan dari kepala sekolah saja melainkan hasil keputusan bersama. Hasil kesepakatan atau persetujuan setelah dilakukan rapat kemudian dibuat SK tim yang sebenarnya. Melalui SK tersebut dapat membuat anggota tim bisa bekerja sesuai dengan tugas dan tanggung jawab yang telah dilimpahkan, sehingga memperjelas yang nantinya harus dilakukan. Karena dalam SK juga terdapat rincian job description masing-masing bagian yang harus dijalankan. Hal tersebut sesuai pendapat dari Asmani (2012: 163) staf membutuhkan pengertian akan langkah-langkah dan prosedur untuk diikuti.

Pelaksanaan pengisian instrumen akreditasi dan bukti fisik di SDN Ketawanggede dilakukan melalui beberapa tahap. Pertama, mengikuti sosialisasi akreditasi sekolah yang diadakan oleh pengawas 
dari Dinas Pendidikan Kota Malang. Pada saat sosialisasi sekolah diberikan perangkat akreditasi yaitu instrumen akreditasi dan petunjuk teknis. Selain itu, pengawas juga memberikan penjelasan dari setiap poin yang ada dalam 8 standar. Kedua, melakukan checklist pada instrumen akreditasi yang diberikan oleh pengawas. Sekolah harus mengisi instrumen akreditasi yang telah diberikan oleh pengawas dengan memberikan tanda centang atau checklist. Checklist tersebut harus diisi pada setiap poin dari masingmasing 8 standar. Pemberian tanda centang dilakukan sesuai target yang ingin dicapai oleh sekolah yaitu memiliki nilai A serta harus didasarkan pada hasil penilaian atau Evaluasi Diri Sekolah (EDS). Hal tersebut sesuai dengan pernyataan dari Kementerian Pendidikan Nasional Republik Indonesia tentang Analisis Sistem Akreditasi Sekolah (2011: 30) bahwa sekolah menerima surat tembusan undangan sosialisasi berisi daftar sekolah yang telah disetujui oleh Badan Akreditasi Provinsi Sekolah/Madrasah (BAP-SM) untuk di akreditasi, beserta perangkat akreditasi dari Unit Pelaksana Akreditasi Sekolah. Perwakilan dari sekolah meghadiri acara sosialisasi akreditasi yang dilaksanakan langsung oleh BAPSM. Setelah menerima perangkat akreditasi, kemudian sekolah mengisi perangkat akreditasi tersebut. Ketiga, melakukan persiapan data yang dijadikan sebagai bukti fisik. Kesiapan datanya ada yang dilakukan jauh-jauh hari sebelum akreditasi dan ada juga yang menjelang akreditasi. Seperti pendapat dari Soedjono (2012: 162) dokumentasi yang dihasilkan bukan hanya berasal dari upaya yang disiapkan dalam waktu singkat, namun melalui proses dan siklus yang cukup panjang. Keempat, melaksanakan pemenuhan bukti fisik sesuai poin yang ada di instrumen akreditasi. Bukti fisik tersebut bisa berupa dokumen yang dimiliki oleh sekolah seperti perangkat pembelajaran atau menggunakan dokumen lomba. Selain itu juga bisa menggunakan foto-foto kegiatan sebagai bukti fisik. Bukti fisik yang telah diperoleh kemudian dimasukkan kedalam map. Hasil temuan penelitian yang serupa dengan temuan penelitian di SDN Ketawanggede juga diperoleh Supriyatno (2013: 148) sebagai berikut, instrumen terdiri dari butirbutir pernyataan sesuai dengan delapan standar pendidikan nasional. Masing-masing butir pertnyataan, harus disiapkan dokumen pendukung sebagai bukti fisik. Guru harus mengisi instrumen yang terdiri dari butir pernyataan. Selain itu, guru juga bertanggung jawab atas bukti fisik serta pengisian instrumen supaya dapat tersusun sesuai kebenarannya. Semua SNP harus dilengkapi dengan bukti fisik yang sesuai dengan keadaan sesungguhnya, benar dilaksanakan serta tidak direkayasa. Susunan instrumen yang sudah lengkap kemudian dimasukkan ke dalam stopmap.

Fakor penghambat dalam persiapan akreditasi di SDN Ketawanggede seperti keterbatasan waktu karena bersamaan dengan tugas dan kegiatan yang lain. Solusi yang dilakukan untuk mengatasi hambatan yaitu membuat jadwal atau mengatur waktu, membuat skala prioritas dan melakukan pembagian tugas. Adanya keterbatasan waktu memang bisa berdampak negatif apabila tidak memiliki skala prioritas yang baik. Seperti pendapat dari Asmani (2009: 149) banyak kegiatan yang harus dilakukan dalam pendidikan sehingga harus bisa memilih mana yang harus segara dikerjakan, mana yang penting dan mana yang bisa ditunda. Menyusun prioritas terkait dengan efisiensi dan efektifitas pendidikan. Permasalahan yang terjadi dalam perisapan akreditasi di SDN Ketawanggede memang pasti akan terjadi. Namun adanya solusi atau alternatif pemecahan masalah diharapkan tidak menghambat dalam melakukan persiapan akreditasi sekolah sebagai upaya untuk melakukan perbaikan. Seperti pendapat dari Fattah (2013: 8) memberikan alternatif solusi dalam upaya peningkatan mutu serta perbaikan di satuan pendidikan. Solusi atau alternatif pemecahan masalah bisa didapatkan melalui berbagai pihak bukan hanya kepala sekolah saja tetapi juga guru dan juga staf. Mengingat anggota yang menjadi tim akreditasi sekolah melibatkan keseluruhan personil sekolah mulai dari kepala sekolah, guru hingga staf. Faktor pendukung dalam persiapan akreditasi di SDN Ketawanggede ada yang berasal dari internal dan juga eksternal sekolah. Faktor pendukung internal seperti adanya bantuan dan motivasi yang diberikan oleh kepala sekolah. Sebagai seorang pemimpin, kepala sekolah memiliki peran penting untuk bisa memberikan arahan dan bimbingan untuk mencapai tujuan bersama. Seperti pendapat dari Mulyasa (2013: 20) kepala sekolah memberikan semangat dan motivasi untuk dapat menghasilkan mutu yang lebih baik serta bersedia memberikan bantuan secara profesional. Faktor pendukung yang berasal dari eksternal sekolah seperti bantuan dari stakeholders sekolah meliputi pengawas sekolah, komite sekolah dan paguyuban sekolah atau orang tua siswa. Seperti pendapat yang disampaikan oleh Satori (2016: 156) tanggung jawab dari pemangku kepentingan (stakeholders) sekolah untuk menetapkan kemajuan serta mendorong sekolah untuk menetapkan prioritas dalam peningkatan mutu. 
Quality control dari proses pengisian instrumen dan bukti fisik di SDN Ketawanggde dilakukan dengan dua cara yaitu melalui pengecekan dan rapat rutin evaluasi persiapan akreditasi sekolah setiap hari jumat. Pengecekan bukti fisik yang dilakukan secara runtut mulai dari masing-masing koordinator standar, ketua tim, kepala sekolah dan pengawas. Pengecekan tersebut dilakukan secara langsung oleh pihak yang memang sudah memiliki keahlian dan kewenangan supaya bisa segera diketahui permasalahan atau proses yang tidak sesuai. Hal tersebut dilakukan sebagai bentuk pengendalian mutu dalam melakukan persiapan akreditasi sekolah. Seperti pendapat yang disampaikan oleh Satori (2016: 138) quality control (pengendalian mutu) adalah suatu sistem untuk mendeteksi terjadinya penyimpangan kualitas output yang tidak sesuai dengan spesifikasi atau standar. Pengendalian mutu ini lebih mempercayakan kepada pihak atau kelompok tertentu untuk melakukan pemeriksanaan kelayakan proses dan produk. Pengecekan lain juga dilakukan dengan mengadakan rapat rutin evaluasi persiapan akreditasi sekolah. Tujuan diadakan rapat untuk mengetahui perkembangan atau progres dari masingmasing standar serta mengetahui semua kendala supaya bisa diatasi segera. Sesuai dengan pendapat yang dikemukakan oleh Mulyasa (2015: 119) setiap rapat sekolah dapat dijadikan sebagai cara melakukan pengendalian mutu karena pada saat rapat berlangsung akan memunculkan pertanyaan dari peserta rapat berkaitan dengan permasalahan yang dialami. Melalui rapat semua personil akan mendapatkan informasi penting yang berguna untuk kemajuan serta peningkatan kinerja.

Tindak lanjut persiapan akreditasi di SDN Ketawanggede dilakukan melalui beberapa upaya. Pertama dengan membiasakan kelengkapan semua perangkat sekolah dengan berorientasi pada mutu. Hal tersebut dilakukan supaya lebih terbiasa dalam melakukan kegiatan apapun arahnya ke mutu yang nantinya menjadi budaya tersendiri di sekolah. Selain itu juga bisa mempermudah pada saat akan ada akreditasi lagi. Seperti pendapat dari Soedjono (2012: 159) Setalah menerima hasil akreditasi, langkah selanjutnya yaitu mempersiapkan akreditasi yang telah terintegrasi dengan proses manajemen sekolah secara lebih berkesinambungan. Kedua membuat rancangan program sekolah yang baru. Hasil yang diperoleh nantinya bisa menunjukkan letak kekurangan dari masing-masing standar. Berdasarkan kekurangan tersebut bisa digunakan sebagai pertimbangan untuk membuat program sekolah yang baru. Seperti pendapat dari Machali dan Hidayat (2016: 375) tindak lanjut berupa perencanaan dan evaluasi program sekolah. Ketiga dengan melakukan penjaminan mutu melalui tim SPMI (Sistem Penjaminan Mutu Internal). Tim SPMI melakukan berbagai evaluasi sehingga penilaiannya sesuai dengan kenyataan dan tidak dimanipulasi. Selain itu juga melakukan pengembangan sekolah sebagai bentuk persiapan akreditasi yang akan datang. Sehingga prosesnya tidak berhenti setelah akreditasi, melainkan selalu berkesinambungan. Seperti pendapat dari Sani (2015: 162) untuk dapat melaksanakan penjaminan mutu pada lembaga pendidikan secara lebih efektif diperlukan adanya tim mutu sekolah.

Terdapat dua strategi keberhasilan yang diterapkan dalam melakukan persiapan akreditasi di SDN Ketawanggede yaitu strategi untuk mendapatkan nilai akreditasi A serta strategi supaya cepat selesai. Strategi yang dilakukan untuk memperoleh nilai A yaitu memiliki target tinggi dan adanya pembagian kelompok dalam SK tim. Sedangkan strategi supaya cepat selesai melakukan pengisian instrumen akreditasi meliputi melakukan kerja sama, koordinasi, komunikasi, saling membantu dan melakukan pembagian tugas. Sesuai dengan pendapat dari Goetsch dan Davis dalam Mutohar (2013: 169) bahwa adanya pembagian tugas dan kewenangan untuk dapat membangun kinerja tim yang bagus dan saling mendukung antara satu dengan yang lain. Pendapat yang serupa juga dikemukakan oleh Asmani (2012: 123) yaitu memiliki target yang tinggi dan terukur dapat dicapai dengan kekuatan fokus, melakukan komunikasi dan koordinasi.

\section{KESIMPULAN DAN SARAN}

\section{Kesimpulan}

Pengelolaan persiapan akreditasi sekolah di SDN Ketawanggede diawalai dengan proses pembentukan tim akreditasi yang mana kepala sekolah menunjuk guru untuk dijadikan sebagai ketua tim akreditasi sekolah, kepala sekolah membuat draft SK yang berisi struktur tim akreditasi, melakukan 
rapat menyampaikan struktur tim akreditasi untuk disepakati secara bersama dan membuat SK tim berdasarkan hasil kesepakatan pada rapat. Pelaksanaan pengisian instrumen akreditasi dan bukti fisik dilakukan melalui beberapa tahap yaitu, mengikuti sosialisasi akreditasi sekolah yang diadakan oleh pengawas dari Dinas Pendidikan Kota Malang, melakukan checklist pada instrumen akreditasi yang diberikan oleh pengawas, melakukan persiapan data yang dijadikan sebagai bukti fisik, dan melaksanakan pemenuhan bukti fisik sesuai poin yang ada di instrumen akreditasi. Faktor penghambat dalam persiapan akreditasi yaitu keterbatasan waktu karena bersamaan dengan tugas dan kegiatan yang lain, adanya guru yang mutasi, penisun dan meninggal dunia, bukti fisik berupa dokumen letaknya tidak beraturan dan bukti fisik berupa foto terkadang tidak ada kerena banyak kegiatan yang sudah dilakukan tetapi tidak di dokumentasikan, dan fasilitas yang kurang memadai. Faktor pendukungnya yaitu adanya bantuan dan motivasi yang diberikan oleh kepala sekolah, kerja sama yang baik antar seluruh tim akreditasi sekolah, bantuan dari stakeholders sekolah, dan dokumen yang dimiliki sekolah meliputi data Evaluasi Diri Sekolah (EDS) dan dokumen yang digunakan saat lomba. Quality control dari proses pengisian instrumen akreditasi dan bukti fisik dilakukan melalui beberapa cara yaitu pengecekan bukti fisik yang dilakukan secara runtut mulai dari masing-masing koordinator standar, ketua tim, kepala sekolah dan pengawas, dan rapat evaluasi persiapan akreditasi sekolah setiap hari jumat. Tindak lanjut hasil akreditasi dilakukan melalui beberapa upaya yaitu membiasakan kelengkapan semua perangkat sekolah dengan berorientasi pada mutu, membuat rancangan program sekolah yang baru, dan melakukan penjaminan mutu melalui tim SPMI (Sistem Penjaminan Mutu Internal). Strategi keberhasilan dalam akreditasi di SDN Ketawanggede ada dua. Strategi pertama dilakukan untuk memperoleh nilai A dan strategi supaya cepat selesai melakukan pengisian instrumen akreditasi dan bukti fisik.

\section{Saran}

Berdasarkan kesimpulan di atas terdapat beberapan saran untuk penelitian selanjutnya yang relevan dengan subjek penelitian ini (1) Kepala Dinas Pendidikan Kota Malang, disarankan agar lebih memaksimalkan pemantauan atau monitoring ke sekolah pada saat melakukan persiapan akreditasi, (2) Kepala SDN Ketawanggede, disarankan agar melakukan tindak lanjut pada saat persiapan akreditasi yang bersifat jangka pendek, sehingga bisa menjadikan sebagai bahan pertimbangan untuk melakukan perbaikan, pengembangan sekolah dan peningkatan mutu, (3) Ketua Jurusan Administrasi Pendidikan disarankan agar memberikan pembahasan mengenai akreditasi sekolah dalam pembelajaran di kelas, karena akreditasi menjadi salah satu hal penting bagi sekolah yang juga harus dilakukan manajemen secara tepat, dan (4) Peneliti lain yang memiliki tema penelitian serupa disarankan agar mengembangkan temuan penelitian mengenai persiapan akreditasi sekolah di situs penelitian yang lain.

\section{DAFTAR RUJUKAN}

Asmani, J.M. 2009. Manajemen Pengelolaan dan Kepemimpinan Pendidikan Profesional. Yogjakarta: Diva Press. Asmani, J.M. 2012. Tips Sakti Membangun Organisasi Sekolah. Yogjakarta: Diva Press.

Fattah, N. 2013. Sistem Penjaminan Mutu Pendidikan. Bandung. PT Remaja Rosdakarya.

Hendarman. 2014. Kendala-Kendala Pelaksanaan Evaluasi Diri Sekolah (EDS). Jurnal Pendidikan dan Kebudayaan. 20 (1), Program Pascasarjana. Universitas Pakuan Bogor dari http://jurnaldikbud.kemdikbud. go.id/index.php/jpnk/article/viewFile/134/124

Kementerian Pendidikan Nasional Republik Indonesia. 2011. Kajian Analisis Sistem Akreditasi Sekolah/ Madarasah Dalam Rangka Reformasi Birokrasi Internal dari https://luk.staff.ugm.ac.id/atur/rbi/ AkreditasiSekolahMadrasah.pdf

Kurniadin, D dan Machali, I. 2012. Manajemen Pendidikan: Konsep dan Prinsip Pengelolaan Pendidikan. Yogyakarta: Ar-Ruzz Media.

Machali, I dan Hidayat, A. 2016. Education Management: Teori dan Praktik Pengeolaan Sekolah/Madrasah di Indonesia. Jakarta: Prenadamedia group.

Mulyasa. 2013. Manajemen dan Kepemimpinan Kepala Sekolah. Jakarta: Bumi Aksara.

Mulyasa, D. 2015. Pendidikan Bermutu dan Berdaya Saing. Bandung: PT Remaja Rosdakarya.

Mutohar, P.M. 2013. Manajemen Mutu Sekolah. Yogyakarta: Ar-Ruzz Media. 
Pedoman Akreditasi BAN-SM. Badan Akreditasi Sekolah/Madrasah dari http://bansm.or.id

Peraturan Pemerintah Nomor 32 Tahun 2013 Tentang Perubahan Atas Peraturan Pemerintah Nomor 19 Tahun 2005 Tentang Standar Nasional Pendidikan. Kemenristekdikti dari http://kelembagaan.ristekdikti.go.id/wpcontent/uploads/2016/08/PP0322013.pdf

Sagala, S. 2013. Memahami Organisasi Pendidikan: Budaya dan Reinventing Organisasi Pendidikan. Bandung: Alfabeta.

Sani, R.A, Pramuniati dan Mucktiany. 2015. Penjaminan Mutu Sekolah. Jakarta: Bumi Aksara.

Satori, D. 2016. Pengawasan dan Penjaminan Mutu Pendidikan. Bandung: Alfabeta.

Soedjono. 2012. Pengembangan Model Penyelenggaraan Akreditasi Sekolah Menengah Atas Di Kota Semarang. Jurnal Manajemen Pendidikan, 1 (2), Program Pascasarjana, Universitas Negeri Semarang dari http://journal. upgris.ac.id/index.php/jmp/article/view/267

Supriyatno, Supriyanto, E dan Maryadi. 2013. Pengelolaan Akreditasi Sekolah (Studi Situs SD Negeri 2 Mranti Kecamatan Purworejo Kabupaten Purworejo). Jurnal Penelitian Humaniora, 14 (2), Program Studi Magister Pendidikan, Universitas Muhammadiyah Surakarta dari http://journals.ums.ac.id/index.php/humaniora/ article/view/862

Undang-Undang Nomor 20 Tahun 2003 tentang Sistem Pendidikan Nasional. Yogyakarta: Pustaka Yustisia. 